\title{
The commons as a paradigm shift for a regenerative Anthropocene
}

doi) https://doi.org/10.21814/anthropocenica.3523

\section{Paulo Magalhães}

Common Home of Humanity, Center for Legal and Economic Research (CIJE), University of Porto, Instituto Geofísico da Universidade do Porto

Portugal

paulo.magalhaes@commonhomeofhumanity.org

ORCID: 0000-0002-2602-0419

\section{Álvaro Costa}

Research Centre for Territory, Transports and Environment (CITTA), University of Porto, Faculty of Engineering

Portugal

afcosta@fe.up.pt

ORCID: 0000-0002-2275-6947

\section{Gabriela Morello}

Common Home of Humanity, Center for Legal and Economic Research (CIJE), University of Porto, Instituto Geofísico da Universidade do Porto

Portugal

gabriela.morello@commonhomeofhumanity.org

ORCID: 0000-0002-5439-969X

\section{Ana Luísa Guimarães}

Common Home of Humanity, Center for Legal and Economic Research (CIJE), University of Porto, Instituto Geofísico da Universidade do Porto

Portugal

ana.guimaraes@commonhomeofhumanity.org

ORCID: 0000-0003-3510-0338

\section{José Viegas}

Civil Engineering Research and Innovation for Sustainability (CERIS), Técnico, University of Lisbon

Portugal

josemviegas@gmail.com

ORCID: 0000-0001-8046-6385

\begin{abstract}
As the Earth System's trajectory approaches an irreversible path towards a "Hothouse Earth", societies remain unable to collectively ensure the maintenance of a stable climate. Nearly 30 years have passed after climate change was considered a Common Concern of Humankind, a status that remains the legal framework adopted by the Paris Agreement, it is inevitably linked to lack of results. A stable climate is a manifestation of the stable and well-defined functioning of the Earth System. Although intangible, a stable climate exists in the real world and is necessarily a common good for being indivisible, limited, exhaustible, and non-excludable. Thus, a congruent system between the rules of appropriation (negative impacts) and provision of the global public good (positive impacts) is necessary for the effective management of the common good - stable climate. However, in the current legal framework that considers a stable climate a Common Concern of Humankind, a stable climate is invisible to our international legal system and economy, which makes it impossible for it to become an object of international governance. Here, the authors argue
\end{abstract}


that the recognition of a stable climate as the Common Heritage of Humankind is the first and fundamental step for being able to act towards restoring and maintaining a stable climate.

\title{
Keywords
}

Climate Heritage; Paris Agreement; Public Common Good; Regenerative Economy; Common Concern of Humankind; Common Heritage of Humankind.

\begin{abstract}
Resumo
À medida que a trajetória do Sistema Terrestre se aproxima de um caminho irreversível em direção a uma "Hothouse Earth" ou "Planeta Estufa", as sociedades permanecem incapazes de garantir coletivamente a manutenção de um clima estável. Quase 30 anos se passaram desde que as mudanças climáticas foram consideradas uma Preocupação Comum da Humanidade, o status que permanece o quadro de referência legal adotado pelo Acordo de Paris, e que está inevitavelmente ligado à falta de resultados. Um clima estável é uma manifestação do funcionamento estável e bem definido do Sistema Terrestre. Embora intangível, um clima estável existe no mundo real e é necessariamente um bem comum por ser indivisível, limitado, esgotável e não excludente. Assim, um sistema congruente entre as regras de apropriação (impactos negativos) e provisão do bem público global (impactos positivos) é necessário para a gestão eficaz do bem comum - clima estável. No entanto, no atual quadro jurídico que considera o clima estável uma Preocupação Comum da Humanidade, um clima estável é invisível para o nosso sistema jurídico e economia internacional, o que impossibilita que se torne um objeto de governança internacional. Aqui, os autores defendem que $o$ reconhecimento de um clima estável como Património Comum da Humanidade é o primeiro e fundamental passo para podermos atuar no sentido de restaurar e manter um clima estável.
\end{abstract}

\section{Palavras-chave}

Estabilização do Clima; Acordo de Paris; Bem comum público; Economia Regenerativa; Preocupação comum da humanidade; Património Comum da Humanidade.

\section{Introduction: a hidden problem}

When climate change entered the United Nation (UN)'s Agenda in the 1980 s, a completely new question emerged: What is a stable climate from a Legal Standpoint? After Malta's proposal in 1988 of recognizing a stable climate as a Common Heritage of Humankind, countries chose to consider climate change as a Common Concern of Humankind.

A stable climate can be defined as a manifestation of the stable and welldefined functioning of the Earth System, operating within the limits for natural variability observed after the last glaciation period (the Holocene Epoch), which resulted in a rich functional biodiversity. The patterns of the envelope natural variability ensures well-defined climate seasons, as well as mild temperature ranges that allow for the maintenance of life cycles. Because climate is not a territorial object, but rather a pattern of the functioning of the Earth System, i.e. the planet's software, which operates as a complex single whole, it is absolutely impossible to divide it in any way, even if in a legal abstract way.

The dynamics of the Earth System challenges the very foundations of International Law, for being subversive to any type of territorial division. Overcoming this paradigm by organizing the relations of interdependence that emerge from the shared use of a single, indivisible, and highly interconnected Earth System, at a global scale, is certainly the biggest challenge that humanity faces to save our common future from the abyss of climatic and environmental catastrophe. 
Almost 30 years after climate change was considered a Common Concern of Humankind - and although this remains the legal framework adopted by the Paris Agreement - there is still no clear definition of what the legal implications of this approach are. A Common Concern is a vague political formula that does not legally recognize the existence of a borderless global public good - stable climate - as would have happened if the Maltese 1980's proposal of recognizing a stable climate as a Common Heritage of Humankind had been accepted.

With the refusal to legally recognize the existence of a stable climate as a common good, which although intangible, exists in the real world and is necessarily a common good for being indivisible, limited, exhaustible, and nonexcludable, the remaining option was to address climate change by implementing a system of mitigation commitments between States, a consequence of approaching climate as a Common Concern of Humankind. Although the legal status of climate seems to be a pure theoretical issue, it is really a structural issue that determines all subsequent negotiations and climate policies. Inevitably, recognizing climate as a Common Concern of Humankind definitively marked the strategy for approaching the climate crisis, and is directly linked to the lack of results that turned a crisis into an emergency.

Despite the climatic emergency, considering climate as a Common Concern of Humankind continues to be consensual and taken for granted, hiding the fact that the structural reason for the failure in fighting climate change lies largely in this option. The most significant issue that remains hidden is that without the definition and recognition of the existence of the global common stable climate, it is not possible to address the climate emergency as a problem of managing commons. This is where all the issues come together. Economic science has already developed a series of structural principles that have made viable what was previously an impossibility in the classical economic doctrine: successfully managing commons. Logically, the first step to be able to manage a common good is to recognize and define the common good that is at stake.

This fundamental step was rejected in the 1988's decision and maintained at the 1992 Earth Summit and Paris Agreement, which was the opportunity to recognize the existence of a functional and intangible common good that spans across and beyond borders. We were left, therefore, with a burden-sharing approach option of damage containment and sharing of expenses, in which each country commits itself to reduce the damages that they caused. The rejection of approaching climate as a Heritage closed the door for all the implications that the recognition of a common good that spans across borders would entail in the overall functioning of global economy, once this legal solution can be seen as a system for internalizing what today is considered as an "externality". Considering that this internalization is both for negative and positive externalities, climate as a Heritage would substantially impact the concept of value and what is considered as creation of wealth in societies. Our current approach of 
considering climate as a Concern is an attempt to mitigate the problem by avoiding any paradigm shift. Moreover, this solution has resulted on a negativesum game, in which the total stable climate resource constantly decreases, even when small damage reductions are achieved, as demonstrated by the current reality of the climate crisis.

The main issue with the current Concern approach is that it does not legally recognize the global public good, stable climate, as a Common Heritage, i.e. a true global common and, for this reason, all the benefits that contribute to maintaining a stable climate disappear from a legal perspective, in what we can call a global legal gap. Consequently, these benefits are also invisible to the economy, which explains the so-called Amazon Paradox (Magalhães, Steffen \& Galli, 2019).

The Amazon crisis is, in its essence, the result of a paradox not resolved by international law, which is a consequence of a structural issue that underlies the climate emergency: the legal and consequently socioeconomic invisibility of the biochemical and intangible work from nature. The fact that the Earth System/stable climate public good is legally non-existent provoked a fundamental conflict between the concept of tangible territorial sovereignty - which has welldefined territorial limits - and the global functioning of the Earth System, which is global, indivisible, does not respect any territorial boundaries, and is intangible.

The Amazon, one of the most critical ecosystems for maintaining the proper functioning of the whole Earth system, is inevitably at the center of this paradox. There is a paradoxical contradiction between its vital value to humanity and the way in which today's economy recognizes the creation of value and wealth: the extraordinary ecological importance of the Amazon cannot be measured in $\mathrm{km}^{2}$, or tons of wood, soy or meat; instead, it should be measured in terms of the total amount of biochemical functions and physical processes that this ecosystem provides for the Earth system. The value of Amazon's fundamental role in maintaining the smooth functioning of global biogeophysical cycles is incomparably superior to the value of the commodities that can be extracted from it. However, unfortunately, because the "good" (Earth system) to which these biochemical benefits are produced, does not legally exist, this natural "work" is also legally non-existent, and consequently considered as "external" and invisible by the economy. In other words, because this work is globally dispersed, we cannot touch, divide or store it, i.e. because it is intangible, it is ignored by law and considered an externality for the economy (Magalhães, Steffen \& Galli, 2019).

Therefore, the current mitigation approach of the States makes it technically impossible to produce the necessary positive contributions for the recovery of a stable climate, which also means that it makes it impossible to build an economy and a society capable of managing the use of a common good and restore the proper functioning of the Earth system. 
"Currently there are no economic mechanisms designed to pay for negative emissions" ( Energy \& Climate Intelligence Unit, 2018, p. 4), or for other impacts beyond just $\mathrm{CO}_{2}$ reduction, that contribute to the maintenance and/or restoration of a well-functioning Earth System. For not being visible in the GDP of nations, these impacts are left out of any governmental decision-making process, and it is impossible to create an economy that restore and maintains the global public good - stable climate.

The application of the concept of Common Concern perpetuates the maintenance of the existing paradigm in which the creation of wealth, regarding to nature, is based almost exclusively on extraction and destruction of ecosystems, while societies seem to remain unaware of this issue. Changing this generally accepted rule of destruction that has underlain our economy requires the development and implementation of a critical legal innovation that accommodates and fits the global common of which we are part and on which we depend.

We currently have the necessary scientific knowledge to define as a Common Heritage, both qualitatively and quantitatively, this intangible asset that supports life on Earth, i.e. the necessary biogeophysical conditions that correspond to the proper functioning of the Earth System. The definition of these conditions within a Safe Space for Humanity (Rockström et al., 2009), by applying the Planetary Boundaries concept (Rockström et al., 2009; Steffen et al., 2015), can serve as the scientific tool to define the necessary legal support as the base of a congruent system between the rules of appropriation (negative impacts) and provision (positive impacts) produced on the global public good. It is undeniable that we have been systematically lacking the most basic requirement for making any human endeavor possible: an appropriate legal framework. A common good must be legally defined and recognized so that it can become manageable as such. After 25 years past the first Conferences of the Parties, it is of utmost importance to reopen the discussion about the legal status of climate.

Legally recognizing the Earth System's Safe Operating Space of Humankind will certainly be an innovation that will substantially enhance the ability of the international legal framework to accurately represent the highly interconnected natural world. Similarly, to changing the initial condition of a system, this paradigm shift can trigger positive cascading effects across the international socio-economic organization.

\section{Climate: the first global common that spans across and beyond borders}

This option of addressing climate as a Concern (UN Resolution 43/53, 1988) remains the formal framework in which we still operate, including the Paris Agreement, and definitely shaped the way in which societies are tackling climate 
change. Despite the calls for the future evolution and attempts to achieve a clear definition of the content of the Concern concept in terms of rights and obligations, climate negotiations have bypassed the necessary conceptual/structural discussions, since this concept's approval by the UN Framework Convention on Climate Change $^{1}$ (UNFCCC).

Thus, whether we want it or not, the substantive content and characteristics of the Concern concept are inevitably linked to the (lack of) results achieved.

- Common Concern of Humankind is a derivative concept from the Common Heritage of Humankind, exclusively founded in the territorial dimension of the planet, and thus addresses tangible resources, with all the subsequent conflicting interpretations;

- Common Concern does not require the existence of a legal object (Heritage), but rather it exists on the subjective side of a collective human feeling, i.e. concerned community (Shelton, 2009), representing one collective willingness to act to achieve a common goal. Common Concern is "a general concept which does not connote specific rules and obligations, but only establishes a general basis for the community to act" (Shelton, 2009, p. 3);

- The Concern approach is focused on the mitigation of one problem, and not on building a permanent system of management or restoration of a common good (stable climate). It is rather an appeal to equitable sharing (Shelton, 2009) of burdens resulting from a problem (climate change);

- "It is hard to define the Common Concern of Humankind concept, particularly as 'concern' could apply to the 'causes' as well as to the "responses" of the problem" (Trindade \& Attard, 1990, cited by Horn 2004, p. 233);

- The Concern element presupposes nothing more than that the States are objectively invited for joint and concerted actions;

- Climate change as a Common Concern has only created "a general framework for possible future legal developments to deal with global environmental challenges" (Tolba, 1991, p. 243), but it was not a legal development itself.

The solution put forward in 1988 (UN Resolution 43/53), and consecrated at the Rio Earth Summit,1992, must be seen in the context of the reality of that time, when a technical solution had not yet been developed for an absolute new problem that creates an "inextricable link between the activities of states within

\footnotetext{
1 The UNFCCC entered into force on 21 March 1994. Today, it has near-universal membership. The 197 countries that have ratified the Convention are called Parties to the Convention. The UNFCCC is a "Rio Convention", one of two opened for signature at the "Rio Earth Summit" in 1992.
} 
national territory and its effects on climate (...) an unprecedented situation in international law" (Borg, 2007, p. 6).

The approach of the UN Resolution 43/53 on climate change indicated a new path based on the conviction that the Common Concern concept would prevent States from having to deal with controversial Common Heritage objects that often end up in dispute of tangible resources. This option does not enable the development of one economy of caring for the commons, and all the cascading effects that can emerge from this paradigm shift, because it does not recognize a new object of international law and, thus, does not allow for the development of a system of governance of a truly global common. Instead, the decision of establishing climate change as a Concern resulted in a commitment to mitigate the problem. Unfortunately, because there is not any institutional solution responsible for managing the governance of the global common, this option resulted in "prolonged diplomatic negotiations over voluntary carbon reductions, as embodied in the UNFCCC and COP processes, and have simply not worked yet to cut the continuing and dramatic build-up of $\mathrm{CO}_{2}$ in the global atmosphere" (Boudreau, 2017, p. 42).

\section{Decodifying the Earth System's operating-mode}

The scientific community responded to the challenge to understand and measure the qualitative and quantitative non-territorial, and functional "space", that corresponds to a stable climate and favors the flourishment of life, by developing the concept of Planetary Boundaries - the limits of the planet (Rockström et al., 2009; Steffen et al., 2015). These limits are based on the intrinsic properties of the Earth System defined by a combination of indicators (core drivers), as depicted in Figure 1. Together, the planetary core drivers function as a set of intangible operating instructions about the operating-mode and regulation of the Earth System, analogous to a "genetic code" of the Earth System's functioning. The Planetary Boundaries translate the initial intuitions of Lovelock (Lovelock, 2000) into numbers, describing the state of the Earth system through a set of scientifically established limits that define the state of the Earth System for the past 11,700 years - the Holocene period. The limits set by the Planetary Boundaries must be respected to maintain the Earth System in a favorable state for life. 


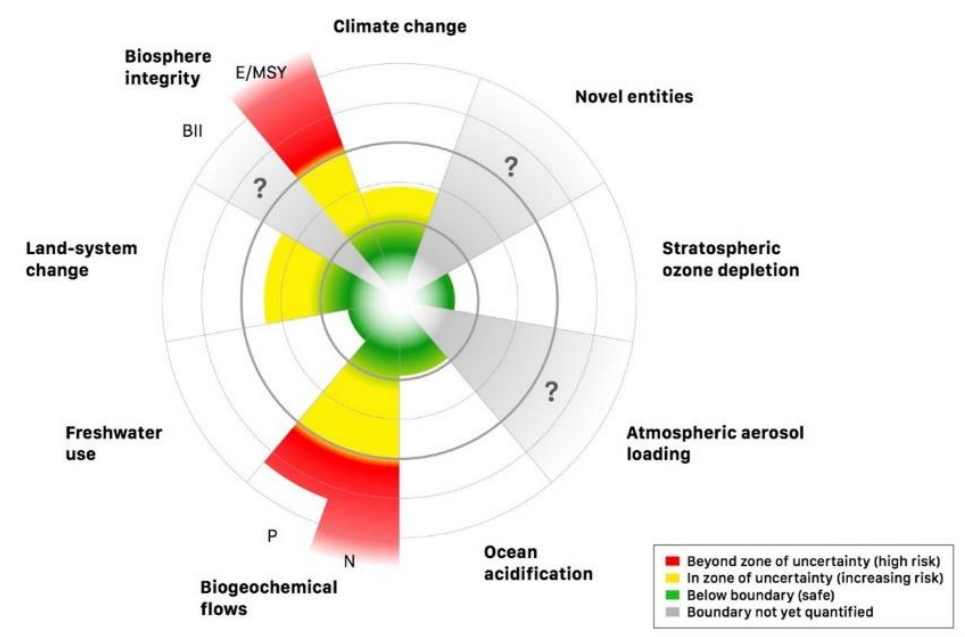

\begin{abstract}
Figure 1. From Steffen et al. (2015). Current status of the control variables for seven of the nine Planetary Boundaries. The green zone is the Safe Operating Space, the yellow represents the zone of uncertainty (increasing risk), and the red is the high-risk zone. The planetary boundary itself lies at the intersection of the green and yellow zone. The control variables have been normalized for the zone of uncertainty; the center of the figure therefore does not represent values of 0 for the control variables. The control variable shown for climate change is atmospheric $\mathrm{CO}_{2}$ concentration. Processes for which global-level boundaries cannot yet be quantified are represented by gray wedges; these are atmospheric aerosol loading, novel entities, and the functional role of biosphere integrity
\end{abstract}

The Planetary Boundaries' framework is based on nine key Earth System processes: climate change, stratospheric ozone depletion, land system change, freshwater use, change in biosphere integrity (including genetic and functional diversity), ocean acidification, biogeochemical flows (as phosphorus and nitrogen cycles), atmospheric aerosol loading and introduction of novel entities. These are the science-based limits to key process that determine the Earth System 's functioning; if the Planetary Boundaries are transgressed, the risk that the Earth System is driven out of the Holocene stability domain increases rapidly. It is important to highlight that the most critical scientific principle that underpins the Planetary Boundaries ' framework is that the Earth System functions as a single integrated system at the planetary level. If a single planetary boundary process is addressed in an isolated way, all the other critical elements that interact with this one will be ignored, as well as all the feedbacks and cascading effects that will happen throughout all the system as result of the interaction of Planetary Boundaries' processes. This means that, more than sectoral, geographic, institutional, and implementation gaps, we face some kind of a substantive gap, a lack of awareness about the need to address the Earth System as single global common, to allow for building a system that enables its restoration and permanent maintenance.

The scientific community referred to the favorable state of the Earth System corresponding to a stable climate, as Safe Operating Space for Humanity. This "space" of safety for humanity is global, interdependent, completely indivisible, 
and therefore an essential common good. These features defy our current social organization which is dominated by a view that believes that the management of common goods inevitably result in a Tragedy of the Common Goods (Hardin, 1968; Schwartz, 2020). With the impossibility of dividing this common good, even in a legal abstract way, the solution has been to try to reduce the magnitude of the tragedy instead of reorganizing the internal human (or social) relations imposed by the shared use of a finite, indivisible, common good, i.e. the Earth System's favorable state for life. Today, however, we have available the necessary knowledge and tools for enabling collective action for the appropriate management of the common good to restore the Earth System functioning and stabilizing climate.

We are being pushed into a global order that, due to its scale and total interdependence, we are not even able to understand or explain, but whose effects are already felt. However, anyone who wishes to progress at the end of this century cannot ignore this reality. "The battleground of the twenty-first century will pit fundamentalism against cosmopolitan tolerance". (Giddens, 1999, p.26)

This new global order has been randomly emerging in an anarchic way, not conducted by a human collective will, and driven by a mix of influences of species. In this current disorder, the nationalisms and local populism bloom, as a response to unregulated globalization trends, in the illusion that nation-States will become stronger by closing their borders, while in reality what is happening is quite the opposite.

The chance of changing this fatal scenario depends primarily on the definition of the global common that will be the object of a new model of governance.

Gobalization is not a simple process, it is a complex network of processes which, in addition, operate so contradictory or in open opposition. For most people, globalization is just an "exchange" of power or influence, from local communities or Nations to the global arena. We need to rebuild the institutions that we have, or replace them, by others. Because globalization is not a transient incident in our lives (Giddens, 1999). It is a change of circumstances in which we live, "a complex set of processes, not a single one" (Giddens, 1999, p. 31). To overcome these challenges, we must rethink the fragmentary nature of the international legal system.

In this sense, the organization of these common interests requires an empowerment that will allow its permanent management by an independent entity to act in the name and interest of all, and where all are properly represented. Concisely understanding the Anthropocene allows us to address globality and interdependence, as well as to think systemically across boundaries. It is impossible to "export" or isolate the impacts of human activities (positive or negative) across the globe on the environment, due to the interconnected nature 
of ecological systems, which in turn, results in political and economic interdependencies. These imposed interdependencies became evident in the context of the Anthropocene and are the outward signs of something that was never acknowledged before: a global cosmopolitan society. We are the first generation to live in a society whose contours we are still barely able to glimpse, and for which there is not yet a system of human organization able to deal with the global interconnections of the Earth System. As stated by Nakicenovic, Rockström, Gaffney \& Zimm (2016):

The Anthropocene is the defining concept of our age. The most significant implication for life in the Anthropocene is the urgent need to shift to a new worldview that encompasses the idea of planetary stewardship for the global commons, thereby delivering global benefits. Effective planetary stewardship can be defined as the sum total of societal and individual activities that generate long-lasting prosperity for all and enhance the resilience of the Earth system. To achieve this aim will require a shift in worldviews at all scales, from local community to nation and from regional to global. (pp. 32-33)

The new Anthropocene era brings a new way to view the world, where the thinking in silos must be complemented and framed with a systemic thinking, where the global thinking frames and guides local actions, where the boundaries are regarded only as a necessary level of social organization that is not confused with the global environmental reality, where the environmental phenomena and social phenomena are perceived as interdependent. In the Anthropocene context, Human Ecology is compatible with this new way of looking at the world (Pires, 2014), and can significantly contribute with the development of an antifragmentary view of the united world and give meaning to the contributions of specialized sciences (Steiner \& Markus, 2003) by connecting knowledge that otherwise would be segregated (Borden, 2014).

Only with a systemic and global approach to human-ecological systems, considering the interconnections and interactions of natural and social sciences, it will be possible to harmonize our technological and organizational capabilities within a system of which humans societies are an integral part: the Earth System.

\section{Legal implications of the Planetary Boundaries approach}

Moving from the current scenario, from a Hothouse, to a Stabilized Earth pathway (Steffen et al., 2018) demands much more than a technological transformation or an isolated establishment of carbon pricing regimes. Humanity is an integral element of the Earth System. Consequently, there is an intimate connection between all our activities and their economic cycles and the global 
biogeophysical cycles. The Anthropocene requires that legal systems reflect, in a normative conception, the global functioning of the Earth System, putting at the center of societal organization the chemical, biological, and physical processes, resulting both from the work of nature and human activity, that are conducive to maintaining the Earth System within the Safe Operating Space.

The urgency for a general awareness about the need to address the Earth System as single global common can only progressively impose itself along a path where the limits, gaps, and shortcomings of a disjunctive and simplifying approach that divide in silos what is a single and totally interdependent system, have emerged. In addition, humanity faces problems and conditions in which addressing the complex and global can no longer be avoided. Following the path already taken by natural sciences, it is time for law to make its own inevitable evolution, and build one new legal abstraction capable of addressing the planet as it is on the natural world, without threatening other legal abstractions: the territorial boundaries. This "gap", i.e. the absence of a global systemic approach to the Earth System's functioning, was until recently an imperceptible and unknown gap, which led it to also be a global legal gap.

Still, even without an integrated and systemic approach, a considerable amount of research has been done to analyze how Planetary Boundaries are covered by international conventions. In addition to international conventions, the UN agenda 2030, which consists of a plan of action for people, planet, peace, partnership, and prosperity, has also included some Planetary Boundaries in its approach. Following this Agenda, the international community is required to "protect the planet from degradation, including through sustainable consumption and production, sustainably managing its natural resources and taking urgent action on climate change, so that it can support the needs of the present and future generations" (United Nations, 2015, p. 2), as well as ending poverty and building prosperity. This Agenda provides 17 goals known as the Sustainable Development Goals (SDGs) with a total of 169 targets among them. However, without a favorable condition of the Earth System, within the Safe Operating Space for Humanity, none of these goals and targets can be successfully achieved.

When overviewing all the existing conventions and their relationship with the Planetary Boundaries, it can be noticed that almost all the 9 indicators of the Planetary Boundaries already have their own silo legislation, but there is no legal framework to represent their interconnections and their way of operating within a complex and interconnected system. In addition, a few of the Planetary Boundaries are mostly covered by regional regimes. Table 1, from Barreira \& Magalhães (2019), depicts the main legal instruments and SDGs covering Planetary Boundaries. 


\begin{tabular}{|c|c|c|c|}
\hline Planetary Boundary & $\begin{array}{c}\text { International } \\
\text { Treaty/Convention }\end{array}$ & $\begin{array}{c}\text { Regional } \\
\text { Treaty/Convention }\end{array}$ & SDG \\
\hline Climate Change & $\begin{array}{l}\text { UNFCCC/Kyoto } \\
\text { Protocol/Paris Agreement } \\
\text { UNCLOS }\end{array}$ & $\begin{array}{l}\text { UNECE Convention on Long- } \\
\text { range Transboundary air } \\
\text { pollution and its Protocols }\end{array}$ & $\begin{array}{l}13 \text { and } \\
7,9,11,12,14, \\
15,16 \text { and } 17\end{array}$ \\
\hline $\begin{array}{l}\text { Change in biosphere } \\
\text { integrity }\end{array}$ & $\begin{array}{l}\text { CBD/ Ramsar/ CITES/Bonn } \\
\text { Convention/ UNCLOS/ }\end{array}$ & & $\begin{array}{l}14 \text { and } 15 \\
\text { and } 6,9,11 \\
12,16 \text { and } 17\end{array}$ \\
\hline $\begin{array}{l}\text { Stratospheric ozone } \\
\text { depletion }\end{array}$ & $\begin{array}{l}\text { Vienna Convention/ Montreal } \\
\text { Protocol }\end{array}$ & & $\begin{array}{l}12 \text { and } \\
9,12,16,17\end{array}$ \\
\hline Ocean acidification & $\begin{array}{l}\text { Climate change } \\
\text { regime/Biosphere } \\
\text { regime/UNCLOS }\end{array}$ & & $\begin{array}{l}7,13,14 \text { and } \\
9,12,16 \text { and } 17\end{array}$ \\
\hline $\begin{array}{l}\text { Biogeochemical flows: } P \\
\text { and } N \text { cycles }\end{array}$ & $\begin{array}{l}\text { UNCLOS applies to marine } \\
\text { pollution through } \mathrm{N} \text { and } \mathrm{P}\end{array}$ & $\begin{array}{l}\text { Some marine regional } \\
\text { conventions apply to marine } \\
\text { pollution through } \mathrm{N} \text { and } \mathrm{P} \\
\text { Baltic Sea Convention deals with } \\
\text { eutrophication } \\
1999 \text { Protocol to Abate } \\
\text { Acidification, Eutrophication and } \\
\text { Ground-level Ozone. }\end{array}$ & $\begin{array}{l}6,11,12 \text { and } \\
\text { indirectly } 16 \\
\text { and } 17\end{array}$ \\
\hline Land-system change & CBD/UNCCD & & $\begin{array}{l}2 \text { and } 15 \\
\text { and } 1216 \text { and } \\
17 \text {, }\end{array}$ \\
\hline Fresh water use & $\begin{array}{l}1997 \text { UN Convention on the } \\
\text { Law of the Non-Navigational } \\
\text { Uses of International } \\
\text { Watercourses }\end{array}$ & $\begin{array}{l}1992 \text { UNECE Convention on the } \\
\text { Protection and Use of } \\
\text { Transboundary Watercourses } \\
\text { and International Lakes }\end{array}$ & $\begin{array}{l}6 \text { and } 16 \text { and } \\
17\end{array}$ \\
\hline $\begin{array}{l}\text { Atmospheric aerosol } \\
\text { loading }\end{array}$ & & $\begin{array}{l}\text { UNECE Convention on Long- } \\
\text { range Transboundary air } \\
\text { pollution and its Protocols }\end{array}$ & $\begin{array}{l}9,12 \text { and } \\
16,17\end{array}$ \\
\hline $\begin{array}{l}\text { Introduction of novel } \\
\text { entities }^{2}\end{array}$ & $\begin{array}{l}\text { Montreal Protocol } \\
\text { Stockholm Convention on } \\
\text { Persistent Organic Pollutants } \\
\text { Rotterdam Convention on the } \\
\text { Prior Informed Procedure for } \\
\text { Certain Hazardous Chemicals } \\
\text { and Pesticides in } \\
\text { International Trade } \\
\text { Minamata Convention on } \\
\text { Mercury } \\
\text { Basel Convention on the } \\
\text { Control of Transboundary } \\
\text { Movement of Hazardous } \\
\text { Waste }\end{array}$ & & $\begin{array}{l}9,12 \text { and } \\
16,17\end{array}$ \\
\hline
\end{tabular}

Table 1. From Barreira \& Magalhães (2019). Overview of the main legal instruments of the Sustainable Development Goals (SDG) covering the Planetary Boundaries

Defining the common good, independently of the technical options chosen to define it, should be the first step to move forward on systemically approaching the Earth System as a complex single whole. Although the operating mode of the Earth System is an intangible good, it exists in the real natural world and all forms of life depend on it, including human. Only by closing the gap between

\footnotetext{
2 Plastics are considered a novel entity. Some Conventions tackle this problem with a restrictive approach; these are the 1972 London Dumping Convention, the 1973 Marpol Convention, the UNCLOS and the Basel Convention on Transboundary Movements of Hazardous Wastes. The need to adopt a Convention on Plastics is being under discussion within UN Environment: https://docs.wixstatic.com/ugd/deeae3_775b1aa527a64e04bb603ed3df399880.pdf
} 
theorization of reality and current knowledge about the functioning of the Earth's ecological dynamics can we pursue effective results. This calls upon international law to answer to a fundamental question of regulation and management: "How can a good that belongs to no one be subject to a legal regime?" (Kiss, 1982, p. 122). A significant milestone in the progressive development of international environmental law would be "if by incorporating concepts of modern science, the law can become an integral part of bringing about a better world, rather than facilitating its destruction" (Capra \& Mattei, 2015, p. 1).

\section{Earth System: the ultimate Heritage of Humankind and a new intangible object of international environmental governance}

The state of the Earth System functioning is much more than a concern. The existence of the constituent meta-conditions that allow the existence and development of the constituted life are the greatest vital value for humankind. Moreover, the transmission of a value underlies the concept of Heritage. Therefore, transferring the Earth System in a well-functioning condition is a constituent meta-heritage, which all generations have the right to receive from the previous ones.

If the Earth System is defined as a unique set of interacting physical, chemical, and biological global-scale cycles and energy flows that allow, and are regulated by life on Planet Earth, law must find technical solutions to recognize the relevance of this fact that exists in the natural world, as a fact of the utmost relevance for humankind. If the system that supports life is intangible, we cannot touch it, divide it or store it, and it spreads across the globe in a highly interconnected fashion not respecting any legal abstractions of (political) boundaries, it is up to the legal sciences to find technical solutions capable of representing one common good with these characteristics. This global common although legally indivisible and over which it is not possible to exercise any kind of appropriation, can be subject to depreciation or qualitative improvement by means of human actions. Therefore, it is critical to find technical and legal instruments capable of ensuring its protection, monitoring and maintenance.

The Earth System's transformation is the result of the planet's current situation in which almost all the biogeophysical cycles of the planet are influenced in one way or the other by human activities. The awareness about the fact that human activity now rivals geological forces in influencing the trajectory of the Earth System, made clear that the transformation of the biophysical structure of our Earth System is the greatest threat to humanity, and thus should also be considered as a fact of the utmost relevance for international law. The 
preservation of the functional biogeophysical dimension of our planet should be recognized and integrated within the International Law system.

While many planets have a physical territory, bigger or smaller than that of the Earth, the other planets do not have, as far as we know, a system that has been created by life able to continue to support life. From a legal standpoint, the planet is strictly a territory with 510 million $\mathbf{~ k m}^{2}$, where the global commons are only the leftovers of the territorial divisions of nation-States. Therefore, all the work that nature does to produce the biogeophysical conditions favorable to life does not exist for the Law, and consequently is also invisible to policy making and to the economy.

The legal sciences have for long recognized the existence of intangible legal assets as the solution for the protection of certain interests or assets that have become relevant to human societies, such as the Intangible Cultural Heritage by UNESCO, or Intellectual Property Rights. These solutions, which resorted to the legal recognition of new intangible assets, proved to be structuring for the construction and functioning of today's society. Why not recognize that nature is not only what is touched and seen, but its most valuable dimension is intangible?

The knowledge we have now about the Earth System functioning oblige us to abandon the yet dominant territorial reductionist approach of law, strictly based on nature's physical and biological characteristics, and move towards representing the real intangible biogeophysical characteristics that are the constituent elements of our life support System and regulate the functioning of the Earth System.

While sovereignty is deeply grounded in the concept of the physical territorial space, the Earth System concept is grounded in the quantitative understanding of the intangible planetary functioning. Nevertheless, it seems entirely possible, from a legal approach, to harmonize the co-existence of both.

Theories of International relations distinguish space from place (Giddens, 1990) and have already started to define functional spaces without territory in order to pursue interests, which no State is able to secure in an isolated manner. From a legal standpoint, the Safe Operating Space for Humanity is an intangible global functional and qualitative space without territory, and the Planetary Boundaries concept allows us to objectively measure, define, and delimit what were previously considered indeterminate and diffuse concepts of law, by quantifying and defining the desirable state of the Earth System. This was a substantial step in solving the legal void created by the indeterminate and vague concepts that have characterized national and international environmental legal texts over the last decades. "Expressions such as the Common Concern of Humankind, the Common Interest of Humankind, the Life-Support System, Intergenerational Solidarity, and Ecological Integrity and Sustainability now have a 
set of indicators and numbers that encircle and delimitate what global sustainability is" (Magalhães, 2016, p.290).

Moreover, as a result of the possibility to qualitatively define the key processes that underpin the functioning of the Earth System - the Planetary Boundaries - and to quantitatively measure the favorable biogeophysical structure corresponding to a well-functioning Earth System - the Safe Operating Space for Humanity - we have in place the conditions to identify the favorable state of the Earth System as an intangible global common that shall be subject to a legal regime, able to organize its sustainable and fair use. Nevertheless, more importantly, the objective description of the functioning of the Earth System would be a point of departure to consider as separate legal entities the biogeophysical global-scale cycles and energy flows of the Earth System, and the physical planet containing the space of territorial sovereignties of the States.

The recognition of a well-defined state of Earth System's functioning could be the Locus upon which a system for management of its shared use can be built, with the goal of ensuring its permanent maintenance (Magalhães 2016).

Until now, the legal non-existence of the intangible functional structure of the Earth System has resulted in a model of social organization in which the planetary biogeophysical processes are "invisible" to economic processes; they are considered "externalities" to our societal organization, despite being key vital factors for humankind.

Social sciences have already defined the necessary conditions for the successful management of common goods (Ostrom, 1990; Ostrom, Burger, Field, Norgaard \& Policansky, 1999): these include not only the development of rules for their use and appropriation, but also a permanent system of maintenance and restoration to ensure its long-term functionality. That is, there must be congruence between the rules of appropriation and provision that are required for producing and maintaining the benefits derived from the common resource.

Therefore, an accounting system tracking positive contributions and negative impacts shall be in place in order to change the dominant rule of destruction and consumption as the sole driver of economic growth.

\section{A new concept of value and wealth creation}

There is broad, international scientific agreement that the window of opportunity to avoid breaching the Paris climate target of staying well below $2^{\circ} \mathrm{C}$, is narrowing sharply. To have a chance of limiting warming to $1.5^{\circ} \mathrm{C}$ above preindustrial levels would require a very steep reduction in greenhouse gas emissions, as well as a huge amount of deliberate carbon dioxide removal from the atmosphere - so-called negative emissions. However, as much as it is necessary to cut emissions and remove $\mathrm{CO}_{2}$ from the atmosphere, it is no less 
necessary that critical biomes that play a decisive role in assuring the resilience of the Earth System are restored and preserved. According to a recent study (Griscom et al., 2017) over one third of the measures required between now and 2030 to keep the world on track to stabilize climate could be achieved costeffectively by boosting natural ecosystems. That is to say, the activity of repairing, restoring, and maintaining the global biophysical conditions that ensure a stable climate must become an activity ensured by human societies, and as such, the intangible biogeophysical work carried out by ecosystems must become visible in our economies.

The complex composition of the Earth's atmosphere is continually being produced and regulated by life, and unquestionably vital for regulating and maintaining the Safe Operating Space for Humanity. Thus, how is it possible that the value of a forest only becomes visible in a country's GDP, and in political decisions, on the day it is turned into timber? Why do we still destroy critical biomes, such as tropical forests, that play a critical role in regulating the overall status of our life-support System on Earth, strictly for agricultural purposes? Is the value of commodities higher than the value of the vital intangible biogeochemical work carried out by these biomes to maintain the chemical composition of the atmosphere, clean freshwater and productive soils? What produces more "wealth" for human societies: this intangible work that supports life itself, or the soy?

The root of this problem is on the concept of "value". Aristotle was the first philosopher to explain the difference between value in use, which relates to the value of what it is, and value in exchange, which relates to the market price. The market price does not reflect the absolute value of certain assets, because it does not incorporate the importance of environmental and social sustainability. Due to the inability of capturing the value in use, the economic understanding of 'value' has shrunk the concept into value in exchange. The mindset is similar to the King Midas legend. King Midas's desire of accumulating gold was jeopardizing the possibility of eating. In his desire of wealth, King Midas put at risk his own survival, almost dying of starvation, while being surrounded by gold.

This is a problem of defining value: wealth is a dynamic outcome of an evolutionary historical process that has always reflected a world being transformed socially, legally, politically, and economically. Value is not an objective variable; it is shaped and created based on supply-demand, financial markets, consumer preferences, social norms, etc. (Mazzucato, 2018). This means that new values resulting from the evolution of societies could give rise to new ways of creating wealth, which could produce new desirable behaviors and outcomes. It is now that the law will have to play its role in defining common principles and values. The need for reshaping wealth creation is one of the key reasons to justify the need for the legal recognition of the favorable state of the Earth System as a Common Heritage of Humankind. The definition of a common 
value, a new object of international law, should become the legal structural support of an economy of maintenance and restoration of the Earth System, where all intangible positive and negative 'externalities' are captured and accounted for to build an economy of climate repair and maintenance of the Earth System.

\section{Building an economy to include climate repair and maintenance of the Earth System}

If the positive impacts on the Earth System resulting from the work of ecosystems and human activity (contributing to its maintenance as our Safe Operating Space) become economically visible, this will result in the existence of true costs, and price signals to those who use these benefits. It will also result in an incentive to lower emissions as well as to invest in activities that generate benefits of common interest. The current approach of relying on reducing emissions without changing the patterns of behavior is clearly dysfunctional and leads to economic benefits being only obtained by wiping out ecosystems and destroying biogeophysical cycles. Climate destabilization is among the arising consequences of the current approach.

Reshaping wealth creation requires a new legal regime that defines which activities are recognized as beneficial or detrimental to the common good, Safe Operating Space for Humanity, how to measure these activities' impact, what are the mechanisms underlying their values, what is the entity that ensures the management of this common good, where can its legitimacy be grounded, what is its operating mode, and so forth. But this inevitable process requires the prior definition of the global common good (Safe Operating Space), its legal status (Common Heritage of Humankind) and to whom this good belongs (all of humanity).

All positive impacts generated by human activities and by preserved/ managed nature-based systems must be accounted for and remunerated in the country where they take place. Remuneration of positive impacts generated by human activity should be made through a subsidy per unit of positive impact generated. Regarding the subsidy level, if a tax regime is defined with a certain tariff applied per unit of negative impact, a similar level of subsidy should be paid to reward each unit of positive impact, as the key game changer to shift one economy based on the consumption and destruction of natural resources, for a new one, where the production of natural intangibles is recognized as creating wealth in human societies.

For effective management of the Safe Operating Space as the ultimate global common, the governance system, along with its objectives, principles, and rules, must be perceived by all countries as fair and ultimately beneficial to their 
citizens, to deliver a sense of hope that this system will be able to achieve its defined objectives. This sense of fairness and hope will act as a driver for countries to participate as part of the system, and remain fully engaged with their obligations.

By incorporating in law concepts from modern science with the information collected from space in the recent Earth observation programs to operationalize the management of the common good, we will have the necessary technical and structural conditions to build an economy able to recover and maintain a stable climate.

\section{Final Remarks}

We are close to a critical point of no-return. There is an intimate connection between legal structures and economic models, as well as between economic models and biogeophysical cycles - and these interconnections cannot be meaningfully separated from one another. Therefore, only by interconnecting these areas of knowledge, will effective results be achieved.

Although intangible, the operating mode of the Earth System exists in the real world, and is our life support-System, and is inevitably a common good, both form a legal an economic point of view.

Today, with the recent developments in our knowledge about the functioning of the Earth System, it is possible to understand the chemical, biological, and physical processes of the Earth System that are conducive to maintaining a favorable state for humanity (i.e., the Holocene) and those that act to push the Earth System out of a stable, desirable state.

With this information, we have the opportunity to create the necessary social, political, and legal frameworks for coordinated action on a global scale. This is a massive challenge that must be overcome, as there is no greater crime than depriving the next generations of any hope. Global coordinated action can only be achieved if we manage to develop a legal framework able to represent the favorable pattern of the operating mode of the Earth System, and giving legal existence to the global common that spans across borders and is our life support system. With this newly recognized global common, we can give value to what really matters, i.e. our Safe Operating Space, and the "concept of value can find once again its rightful place at the center of economic thinking" (Mazzucato 2018, p. 18).

\section{References}


Barreira, A. \& Magalhães, P. (2019). El principio de integrida y unidad del sistema terrestre. In: Y. Aguila, C. Perals, V. Tafur \& T. Parejo (Eds.) (2019). Principios de Derecho Ambiental y Agenda 2030 (pp. 405-421). Valencia: Editorial Tirant lo Blanch.

Borden, R. J. (2014). Ecology and Experience: Reflections from a Human Ecological Perspective. Berkeley: North Atlantic Books.

Borg, S. (2007). Climate Change as a Common Concern of Humankind, Twenty Years Later. In: UNGA to UNSC. IUCN Academy of Environmental Law. Towards an Integrated Climate Change and Energy Policy in the European Union. Malta: University of Malta.

Boudreau, T. (2017). The Earth`s Atmosphere as A Global Trust: Establishing Proportionate State Responsibility to Maintain, Restore and Sustain the Global Atmosphere. Environmental and Earth Law Journal (EELJ) 7(1): pp. 39-104.

Capra, F. \& Mattei, U. (2015). The Ecology of Law: Toward a Legal System in Tune with Nature and Community. Oakland: Berrett-Koehler Publishers.

Energy \& Climate Intelligence Unit (2018). Negative emissions: why, what, how? Net Zero. Retrieved from: https://eciu.net/analysis/briefings/netzero/negative-emissions-why-what-how.

Giddens, A. (1990). The Consequences of Modernity. Cambridge. Polity Press.

Giddens, A. (1999). Runaway World. How Globalization Is Reshaping Our Lives. London: Profile Books.

Griscom, B. W., Adams, J., Ellis, P. W., Houghton, R. A., Lomax, G., Miteva, D. A., Schlesinger, W. H., Shoch, D. Siikamäki, J. V., Smith, P., Woodbury, P., Zganjar, C., Blackman, A., Campari, J., Conant, R.T., Delgado, C., Elias, P., Gopalakrishna, T., Hamsik, M. R., Herrero, M., Kiesecker, J., Landis, E., Laestadius, L., Leavitt, S. M., Minnemeyer, S., Polasky, S., Potapov, P., Putz, F. E., Sanderman, J., Silvius, M., Wollenberg, E. \& Fargione, J. (2017). Natural Climate Solutions. Proceedings of the National Academy of Sciences of the United States of America 114(44): pp. 11645-11650.

Hardin, G. (1968). The Tragedy of the Commons. Science 162(3859): pp. 12431248. 
Horn, Laura. (2004). The implications of the concept of common concern of a human kind on a human right to a healthy environment. Macquarie Journal of International and Comparative Environmental Law, 1(2): 233-268. Retrieved from: http://classic.austlii.edu.au/au/journals/MqJIICEnvLaw/2004/10.html.

Kiss, A. (1982). La Notion de Patrimoine Commun de L`Humanité. RCADI (Recueil des Cours de l’Académie de Droit International), 175(2): pp. 99-256.

Lovelock, J. E. (2000). Gaia: A new look at life on Earth. Oxford: Oxford Paperbacks.

Magalhães, P. (2016). Safe Operating Space of Humankind Treaty (SOS Treaty) A proposal. In: Magalhães, P., Steffen, W., Bosselmann, K., Aragão, A., Soromenho-Marques, V. (Eds.). The Safe Operating Space Treaty: A New Approach to Managing Our Use of the Earth System. Newcastle upon Tyne: Cambridge Scholars Publishing.

Magalhães, P., Steffen, W. \& Galli, A. (2019, November 5). The Amazon paradox: Recognising the global contribution of regional ecosystems is vital to combatting climate change and environmental collapse. Together First a Global System That Works for All 1-6. Retrieved from: https://together1st.org/blog/the_earth_system_upon_which_all_life_depends _must_be_legally_recognised_if_it_is_to_be_protected.

Magalhães, P., Steffen, W. \& Galli, A. (n.d.). L'Amazzonia e il Sistema Terra. Panda. World Wide Fund Magazine. 52(4): pp. 18-21

Mazzucato, M. (2018). Il valore di tutto: chi lo produce e chi lo sottrae nell ’economia globale. Bari: Laterza.

Nakicenovic, N., Rockström, J., Gaffney, O. \& Zimm, C. (2016). Global Commons in the Anthropocene: World Development on a Stable and Resilient Planet. International Institute for Applied Systems Analysis (IIASA) Working Paper 16$019 . \quad$ Retrieved form: https://www.iucn.org/sites/dev/files/global_commons_in_the_anthropocene _iiasa_wp-16-019.pdf

Ostrom, E. (1990). Governing the Commons: The Evolution of Institutions for Collective Action. Cambridge: Cambridge Scholars Publishing. 
Ostrom, E., Burger, J., Field, C. B., Norgaard, R. B. \& Policansky, D. (1999). Revisiting the commons: Local lessons, global challenges. Science 284(5412): pp. 278-282.

Pires, I. (2014). Problemas Sociais Complexos: O Olhar da Ecologia Humana. In: R. Alvim \& A. Badiru (Eds.) (2014). Ecologia Humana, Uma Visão Global (pp. 101-121). Feira de Santana: Universidade Estadual Feira de Santana.

Rockström, J., Steffen, W., Noone, K., Persson, Å., Chapin, F. S., Lambin, E., Lenton, T. M., Scheffer, M., Folke, C., Schellnhuber, H. J., Nykvist, B., de Wit, C. A., Hughes, T., van der Leeuw, S., Rodhe, H., Sörlin, S., Snyder, P. K., Costanza, R., Svedin, U., Falkenmark, M., Karlberg, L., Corell, R. W., Fabry, V. J., Hansen, J., Walker, B., Liverman, D., Richardson, K., Crutzen, P. \& Foley, J. (2009). Planetary Boundaries: Exploring the Safe Operating Space for Humanity. Ecology and Society 14(2): $32 . \quad$ Retrieved from: http://www.ecologyandsociety.org/vol14/iss2/art32

Schwartz, P. (2020, March 2). Climate Change: A Tragedy of the Commons? Reflections from Europe. The Library of Economics and Liberty. Retrieved from: https://www.econlib.org/library/Columns/y2020/Schwartzclimatechange.ht $\underline{\mathrm{ml}}$.

Shelton, D. (2009). Common Concern of Humanity. Environmental Law and Policy 39(2): pp. 83-96.

Steffen, W., Richardson, K., Rockström, J., Cornell, S. E., Fetzer, I., Bennett, E. M., Biggs, R., Carpenter, S. R., De Vries, W., De Wit, C. A., Folke, C., Gerten, D., Heinke, J., Mace, G. M., Persson, L. M., Ramanathan, V., Reyers, B. \& Sörlin, S. (2015). Planetary boundaries: Guiding human development on a changing planet. Science 347(6223), 1259855-1-1259855-10.

Steffen, W., Rockström, J., Richardson, K., Lenton, T. M., Folke, C., Liverman, D., Summerhayes, C. P., Barnosky, A. D., Cornell, S. E., Crucifix, M., Donges, J. F., Fetzer, I., Lade, S. J., Scheffer, M., Winkelmann, R., \& Schellnhuber, H. J. (2018). Trajectories of the Earth System in the Anthropocene. Proceedings of the National Academy of Sciences 115(33): 8252-8259.

Steiner, D. \& Markus, N. (2003). Human ecology: fragments of anti-fragmentary views of the world. London: Taylor \& Francis e-Library. 
United Nations (2015). Transforming our world: the 2030 Agenda for Sustainable Development. A/RES/70/1, 35. Retrieved from: https://sdgs.un.org/2030agenda.the

Tolba, M. (1991). The Implications of the "Common Concern of Mankind" Concept in Global Environmental Issues. Revista Instituto Interamericano de Derechos Humanos 13: pp. 237-246.

Trindade, A. C. \& Attard, D. (1990). Report of the Proceedings of the Meeting. In D. Attard (Ed.), The Meeting of the Group of Legal Experts to Examine the Concept of the Common Concern of Mankind in Relation to Global Environmental Issues. Nairobi: UNEP.

Co-financed by: 